

\section{Renewable Energy Project Financing: Impacts of the Financial Crisis and Federal Legislation}

Technical Report NREL/TP-6A2-44930 July 2009

Paul Schwabe, Karlynn Cory, and James Newcomb

Prepared under Task No. SAO7.9B30

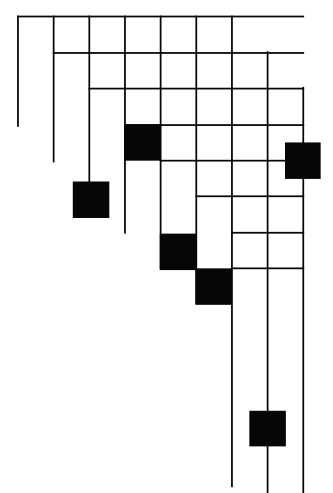




\section{NOTICE}

This report was prepared as an account of work sponsored by an agency of the United States government. Neither the United States government nor any agency thereof, nor any of their employees, makes any warranty, express or implied, or assumes any legal liability or responsibility for the accuracy, completeness, or usefulness of any information, apparatus, product, or process disclosed, or represents that its use would not infringe privately owned rights. Reference herein to any specific commercial product, process, or service by trade name, trademark, manufacturer, or otherwise does not necessarily constitute or imply its endorsement, recommendation, or favoring by the United States government or any agency thereof. The views and opinions of authors expressed herein do not necessarily state or reflect those of the United States government or any agency thereof.

Available electronically at http://www.osti.gov/bridge

Available for a processing fee to U.S. Department of Energy and its contractors, in paper, from:

U.S. Department of Energy

Office of Scientific and Technical Information

P.O. Box 62

Oak Ridge, TN 37831-0062

phone: 865.576 .8401

fax: 865.576 .5728

email: mailto:reports@adonis.osti.gov

Available for sale to the public, in paper, from:

U.S. Department of Commerce

National Technical Information Service

5285 Port Royal Road

Springfield, VA 22161

phone: 800.553 .6847

fax: 703.605.6900

email: orders@ntis.fedworld.gov

online ordering: http://www.ntis.gov/ordering.htm 


\section{Acknowledgments}

This work was funded, in part, by the U.S. Department of Energy's (DOE's) Energy Efficiency and Renewable Energy Commercialization Program. The authors wish to thank participating DOE staff — Wendolyn Holland and Carol Battershell—-for providing useful insights and overall direction in the early stages of this effort. The authors are also grateful for the guidance and helpful input of the project managers, Gian Porro and Bill Babiuch, of the National Renewable Energy Laboratory (NREL). We would also like to thank Rachel Gelman for her extensive background research as well the individuals who reviewed various drafts of this report, including Douglas Arent, Jason Coughlin, Ted James, David Kline, Jeffrey Logan, Margaret Mann, and Michael Mendelsohn, all of NREL. The authors also thank Sean Coletta, MMA Renewable Ventures; Laura Ellen Jones, Hunton \& Williams LLP; Matthew Karcher, Deacon Harbor Financial; Alex Kramarchuk, EyeOn Energy Ltd.; Daniel Sinaiko, Chadbourne \& Parke LLP; and Ethan Zindler, New Energy Finance.

The authors are also grateful to the interviewees for providing their insights into current renewable energy market conditions and for providing additional clarifications. Thank you to Richard Ashby, RES Americas; John Burges, Think Energy Partners LLP; Sean Coletta, MMA Renewable Ventures; Kim Fiske, Iberdrola Renewables; Rob Glen, New Energy Finance; Gaurab Hazarika, Duke Energy; Laura Ellen Jones, Hunton \& Williams LLP; Matthew Karcher, Deacon Harbor Financial; Alex Kramarchuk, EyeOn Energy Ltd.; Lance Markowitz, Union Bank of California; Craig Mataczynski, RES Americas; John McKinsey, Stoel Rives LLP; Stephen O'Rourke, Deutsche Bank Securities; Jerry Peters, TD Banknorth; Charles Ricker, Bright Source Energy; Dale Rogers, eSolar; Partho Sanyal, Merrill Lynch; Daniel Sinaiko, Chadbourne \& Parke LLP; Parker Weil, Merrill Lynch; and Ethan Zindler, New Energy Finance.

Finally, the authors also offer their gratitude to Michelle Kubik in NREL's Technical Communications Office for providing editorial support and to NREL's Jim Leyshon for his graphics support. 


\section{Table of Contents}

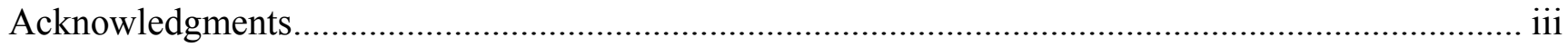

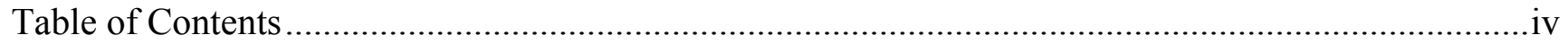

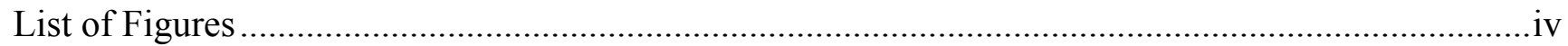

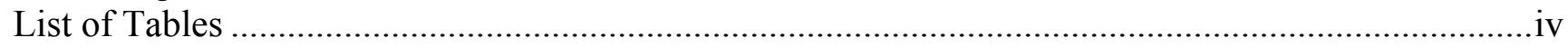

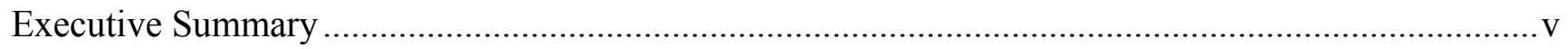

1 The Renewable Energy Project Investment Context ……............................................................ 1

2 Financial Market Factors Affecting Renewable Energy Project Finance........................................... 1

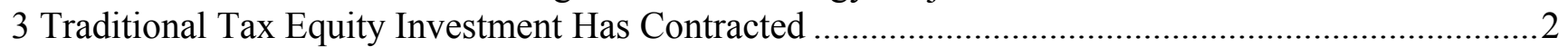

3.1 Renewable Energy Project Investment Yields Significant Tax Benefits....................................2

3.2 Historically, Renewables Attracted Fewer Than 20 Large Tax Equity Investors ..........................2

3.3 Available Tax Equity Investment Will Be Insufficient to Support Near-Term Renewable Energy

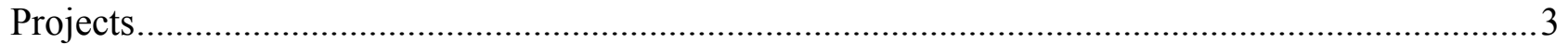

3.4 Upward Pressure on Tax Equity Investment Returns ..........................................................

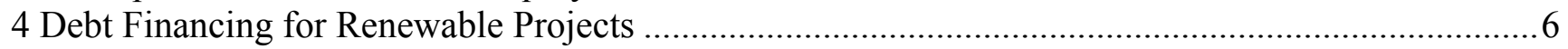

4.1 Illiquid Debt Market Results From the Financial Crisis ................................................................. 6

4.2 Interest Rates on Renewable Energy Debt Unclear; Expected Upward Trend .............................6

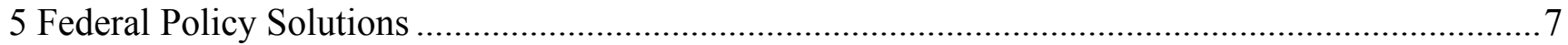

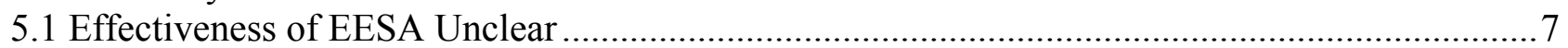

5.2 Effectiveness of ARRA's Renewable Energy Provisions Yet to Be Determined ........................... 8

5.3 Measures to Monitor the Impact of Federal Legislation on RE Project Development................... 9

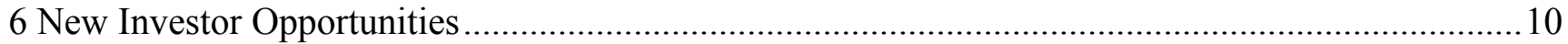

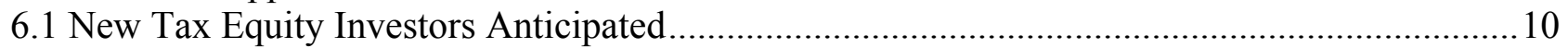

6.2 Utilities Increasingly Interested in Project Ownership and Tax Equity Investments ..................10

7 Factors Influencing Future RE Project Development and Financing ............................................. 11

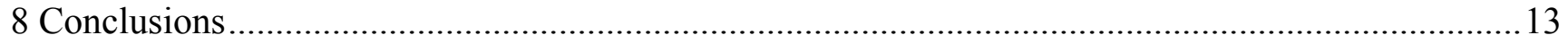

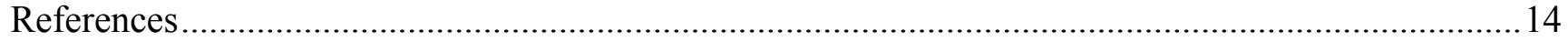

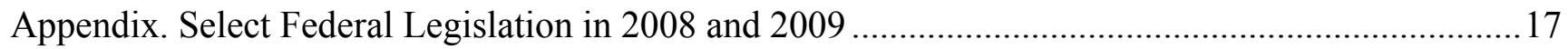

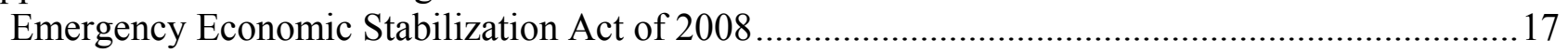

American Recovery and Reinvestment Act of 2009.................................................................... 17

\section{List of Figures}

Figure ES1. Impacts of the financial crisis and federal legislation on renewable energy project

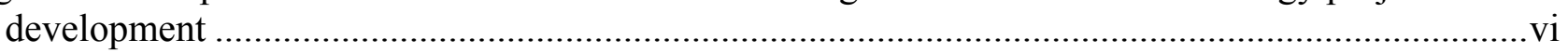

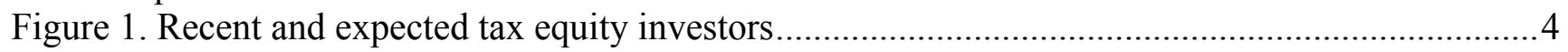

Figure 2. Impacts of the financial crisis and federal legislation on renewable energy project

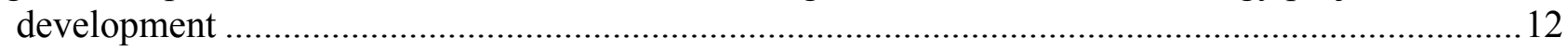

\section{List of Tables}

Table ES1. Summary of Current Financial Issues for Renewable Energy Projects ................................vii

Table A1. Select Tax Provisions Addressing EERE Sectors.................................................................18 


\section{Executive Summary}

Extraordinary financial market conditions have disrupted the flows of equity and debt investment into U.S. renewable energy (RE) projects since the fourth quarter of 2008. The pace and structure of renewable energy project finance has been reshaped by a combination of forces, including the financial crisis, global economic recession, and major changes in federal legislation affecting renewable energy finance. This report explores the impacts of these key market events on renewable energy project financing and development.

Tax credit incentives have been a principal driver of investment in renewable energy projects, but have become largely ineffective in the current economic climate. Reduced corporate tax liabilities have sharply diminished the amount of tax-related investment funneled to renewable energy projects by traditional "tax equity" investors including large investment banks, commercial banks, and insurance companies. The pool of large tax equity investors was small to begin with - including only about 20 institutions in 2008 - but has shrunk to approximately four to six active institutions in early 2009. The amount of tax equity investment available from traditional sources will be insufficient to fully support near-term renewable energy project development. However, utilities and other new investors may increasingly invest in renewable energy projects as new federal provisions become available.

Meanwhile, availability of debt funding to finance renewable energy projects is also limited as a result of global credit tightening. Lenders to renewable energy development are conserving capital and limiting their lending activities. The difficulty in obtaining debt is expected to increase borrowing costs for project developers; however, exact interest rates for debt on renewable energy projects are difficult to discern because relatively few projects are being financed in the commercial market.

U.S. federal legislation passed in February 2009 in response to the economic downturn included two key renewable energy provisions aimed at increasing the availability of financing for renewable energy projects:

- temporary grants provided in lieu of tax credits, and

- loan guarantees for innovative and commercial projects.

At the time of this writing, it is too early to assess definitively the degree to which the enactment of U.S. federal legislation may serve the renewable energy industry from today's market conditions.

Figure ES1 depicts the potential implications of recent events for non-hydro renewable electricity generation. In the wake of the financial crisis, some renewable energy project development has continued. For instance, more than 2,800 MW of wind capacity was installed in the first quarter of 2009 (AWEA 2009b). However, much of the financing for these projects was secured prior to the height of the financial crisis, and commitments were honored by project investors. Accordingly, the most acute impact of the financial crisis on renewable energy project development could be experienced in the second half of 2009. This is the period after the completion of pre-financial crisis commitments, but before the impacts of U.S. federal legislation or broader economic recovery. 


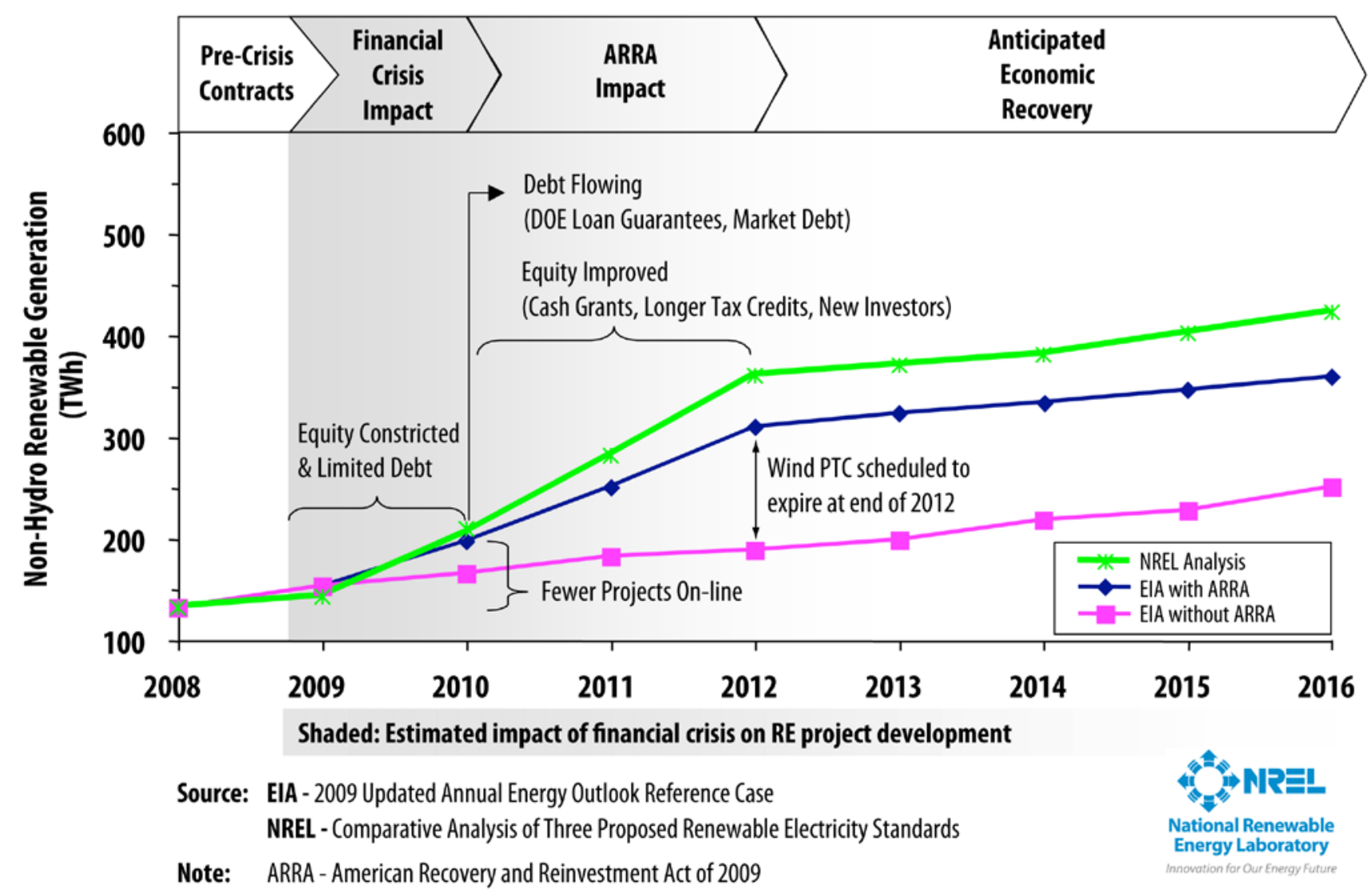

Figure ES1. Impacts of the financial crisis and federal legislation on renewable energy project development

As programs targeting renewable energy project financing and development are implemented, administrative factors could influence their effectiveness. The cash grant and loan guarantee programs included in the 2009 federal legislation will provide crucially needed stimulus to equity and debt investments. Thus, the speed and effectiveness of program implementation and administration will shape the outcomes.

Table ES1 provides a summary of current financial issues impacting renewable energy project development and financing. 
Table ES1. Summary of Current Financial Issues for Renewable Energy Projects

\begin{tabular}{|c|c|c|c|}
\hline \multicolumn{2}{|c|}{ Issue } & \multicolumn{2}{|c|}{ Potential Impact $\quad$ Current Status } \\
\hline 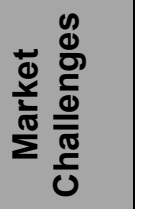 & $\begin{array}{l}\text { The } \\
\text { financial } \\
\text { crisis }\end{array}$ & $\begin{array}{l}\text { Marked slowdown in project } \\
\text { development in } 2009 \text {, with possible } \\
\text { rebound in } 2010 .\end{array}$ & $\begin{array}{l}\text { 1. Projects with financing prior to October } 2008 \text { have } \\
\text { continued to move forward. } \\
2 \text { Many projects envisioned for } 2009 \text { have been delayed. } \\
\text { 3. Impact of new federal legislation will begin to be seen } \\
\text { in } 2009-2010 \text {. }\end{array}$ \\
\hline \multirow{4}{*}{ 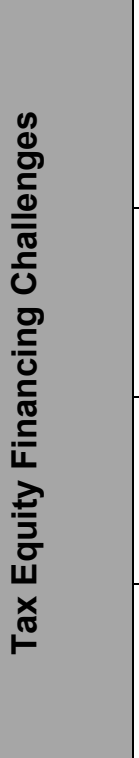 } & $\begin{array}{l}\text { Tax } \\
\text { liability } \\
\text { appetite }\end{array}$ & $\begin{array}{l}\text { New projects have difficulty finding } \\
\text { investors able to efficiently take the } \\
\text { tax credits. }\end{array}$ & $\begin{array}{l}\text { Major investors are absorbing the losses of merged or } \\
\text { acquired companies; their tax appetite has decreased. } \\
\text { Investment tax credit (ITC) and production tax credit } \\
\text { (PTC) rule changes and DOE loan guarantees may help, } \\
\text { but implementation may take several months. }\end{array}$ \\
\hline & $\begin{array}{l}\text { Investor } \\
\text { pool }\end{array}$ & $\begin{array}{l}\text { In } 2008 \text {, RE projects were financed } \\
\text { by less than } 20 \text { traditional RE tax } \\
\text { equity investors. }\end{array}$ & $\begin{array}{l}\text { In early } 2009 \text {, approx. four to six traditional investors } \\
\text { remain active. The new deals getting financed are the } \\
\text { best projects with solid management teams; an investor } \\
\text { "flight to quality." New investors could emerge. }\end{array}$ \\
\hline & $\begin{array}{l}\text { PTC } \\
\text { limitations }\end{array}$ & $\begin{array}{l}\text { If investor pays alternative minimum } \\
\text { tax (AMT), PTC may be limited to four } \\
\text { years. Long-term uncertainty about } \\
\text { PTC remains. }\end{array}$ & $\begin{array}{l}\text { Recovery legislation in } 2009 \text { extended PTC for additional } \\
\text { three years and made it possible to take ITC in lieu of } \\
\text { PTC through } 2012 \text {. }\end{array}$ \\
\hline & $\begin{array}{l}\text { Passive- } \\
\text { loss and } \\
\text { at-risk } \\
\text { rules }\end{array}$ & $\begin{array}{l}\text { It is challenging for individuals to take } \\
\text { PTC and ITC directly, on their income } \\
\text { tax return, or by investing in a fund or } \\
\text { together in a partnership. }\end{array}$ & No changes expected. \\
\hline \multirow{2}{*}{ 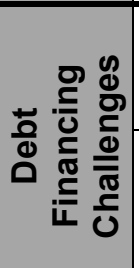 } & $\begin{array}{l}\text { Credit } \\
\text { availability }\end{array}$ & $\begin{array}{l}\text { Credit markets have tightened and } \\
\text { debt liquidity has dramatically } \\
\text { declined. }\end{array}$ & $\begin{array}{l}\text { New federal legislation may help, but the impact on credit } \\
\text { availability remains uncertain. }\end{array}$ \\
\hline & $\begin{array}{l}\text { Debt for } \\
\text { wind }\end{array}$ & $\begin{array}{l}\text { Wind projects use debt (1) for } \\
\text { construction loans and (2) as down } \\
\text { payment to secure wind turbines }\end{array}$ & $\begin{array}{l}\text { RE developers without proper credit may not be able to } \\
\text { use debt for construction costs. With increased risk, } \\
\text { manufacturers might require larger down payments. }\end{array}$ \\
\hline
\end{tabular}




\section{The Renewable Energy Project Investment Context}

The rapid expansion of renewable energy capacity in the United States in recent years has generated an enormous need for project-capital investment. In 2007, solar photovoltaic (PV) installations grew by $45 \%$ (Prometheus 2007), and wind capacity grew $46 \%$, which resulted in an estimated $\$ 9$ billion in investments (DOE 2008). In 2008, PV installations grew by $81 \%$ (SEIA 2009), and the American Wind Energy Association reported that installed wind power capacity grew by $50 \%$, supported by $\$ 17$ billion in investments (AWEA 2009a). In the past few years, renewable energy development has flourished and, until recently, the availability of capital investment had not been a constraint on developing new projects.

Beginning in 2008 and continuing to 2009, conditions shifted with the combined effects of two main forces that influenced renewable energy project development. First, renewable energy tax credits set to expire at the end of 2008 were not reauthorized by the federal government until the fourth quarter of 2008, slowing the pace of investment while investors waited for a decision on the extension of the credits. Second, the financial crisis and the downturn in the U.S. economy slowed renewable energy investment.

The federal government's response to the economic contraction has emphasized broad economic stimulus, including sweeping revisions to renewable energy incentives. However, it remains difficult to assess the degree to which these measures will offset the impact of the economic downturn on the financing of renewable energy projects. This report explores the impacts of market events and recently adopted federal policies that will affect new renewable energy project development. Our analysis focuses primarily on the perspectives of traditional renewable energy project investors as opposed to renewable energy technology advancement investors such as venture capital firms.

To understand the direct impacts of the U.S. financial crisis on renewable project financing, NREL reviewed recent publications and news articles, and conducted a series of interviews with 20 experts in renewable energy finance. Participating organizations included banks and financial service companies, prominent renewable energy developers, law firms, utilities, consultants, and think tanks. The interviews focused on availability and cost of renewable energy capital (including debt and equity), implications on current and future projects, possible actions by the U.S. Department of Energy and the federal government, as well as the impacts of new policies.

\section{Financial Market Factors Affecting Renewable Energy Project Finance}

While renewable energy project installations have flourished in recent years, an extraordinary combination of recent events has reshaped the pace and structure of renewable energy project finance.

First, through much of 2008, investors expected that the production tax credit (PTC) would expire at the end of the year and that the $30 \%$ investment tax credit (ITC) for solar would revert 
back to $10 \%$. This situation accelerated efforts to complete projects in the short term, but undermined development of projects that would need financing in 2009 and beyond. Because the economic benefits of the tax credits could not be relied on for projects financed in 2009 and beyond, planning and development efforts for these longer-term projects slowed.

Second, renewable energy industries were exposed to the highly turbulent financial markets and a contraction of economic activity. The result was a dramatic tightening of credit availability. Several of the largest institutions investing in renewable energy either ceased to exist, skirted solvency, or required government intervention.

In response to the economic crisis, the U.S. Congress passed two pieces of legislation that contained provisions that it hopes will assist renewable energy industry growth. The Emergency Economic Stabilization Act of 2008 (EESA) was passed in October 2008 as an effort to restore confidence and functionality of the financial markets. The American Recovery and Reinvestment Act of 2009 (ARRA), signed in February 2009, offered nearly $\$ 800$ billion in tax cuts and spending to promote economic recovery (Weiss 2009). The extent to which these measures will succeed in stimulating a resurgence remains unclear. However, the provisions encompassed in these two pieces of legislation, taken together, bring far-reaching changes to the landscape of renewable energy project finance.

\section{Traditional Tax Equity Investment Has Contracted}

The economic downturn has had a direct and severe impact on investment in renewable energy projects, reducing the ability of project owners to take advantage of tax incentives.

\subsection{Renewable Energy Project Investment Yields Significant Tax Benefits}

The U.S. federal government has incentivized new renewable energy projects by offering sizeable federal tax credits and deductions to companies and homeowners that invest in renewable energy systems. In addition to the PTC and ITC, commercial and industrial owners of renewable energy projects also are able to accelerate the depreciation of qualifying renewable energy equipment through the Modified Accelerated Cost Recovery System (MACRS). The economic value of the combined tax benefits ${ }^{1}$ is considerable - close to $50 \%$ of a solar photovoltaic system's installed cost can be recovered through the ITC and accelerated depreciation (Cory et al. 2009). For a wind project using the PTC, the present value of the combined tax benefits sometimes can exceed the system's cash revenues from the sale of electricity and renewable energy certificates ${ }^{2}$ (RECs) (Harper et al. 2007).

\subsection{Historically, Renewables Attracted Fewer Than 20 Large Tax Equity Investors}

Renewable energy project developers typically do not have tax liabilities large enough to efficiently capture the full amount of tax credits available for large projects. To overcome this,

\footnotetext{
${ }^{1}$ The combined tax benefits are PTC and MACRS for wind, and ITC and MACRS for solar. Neither of the estimates for solar or wind include the MACRS bonus depreciation schedule in place in 2008 and $2009-50 \%$ in the first year.

${ }^{2}$ This will be dependent on a number of location-specific factors that are constantly changing, including amount of wind generated, electric generation price, and local REC prices. For a while, this was true in Texas, until transmission constraints led to wind generation curtailment.
} 
developers partner with passive "tax equity investors" to efficiently use the federal tax benefits generated by their projects. A tax equity investor typically invests in a renewable energy project by contributing capital investment, which secures tax benefits and a return on investment from the project.

Traditionally, tax equity investors have been very large, tax-paying corporations seeking to offset some portion of their expected tax liability. In the past few years, fewer than 20 U.S. taxable entities acted as tax equity investors, including large investment banks, commercial banks, or insurance companies (Chadbourne \& Parke 2009b). The pool of such investors was highly concentrated in the financial industry and included AIG, CitiBank, Wachovia, Lehman Brothers, Merrill Lynch, and Wells Fargo, among others.

The number of tax equity investors was small for several reasons. First, tax equity investors must have prohibitively large tax liabilities to absorb the tax credits. In the case of the PTC, this tax liability must remain for 10-11 years to efficiently use the tax credits. Second, prior to the enactment of EESA, the alternative minimum tax (AMT) ${ }^{3}$ nullified potential benefits of the credits for some potential investors, primarily because corporations paying the AMT were not allowed to take the ITC. Third, barriers to noninstitutional investors, known as "passive-loss and at-risk rules," made it challenging for individuals to take the PTC and ITC directly on their personal income taxes. Thus, partnerships of high net-worth individuals with large tax appetites were not significant investors in renewable energy tax equity investments. Together, these factors prevented otherwise interested tax equity investors from investing in renewable energy projects for tax-benefit purposes.

\subsection{Available Tax Equity Investment Will Be Insufficient to Support Near-Term Renewable Energy Projects}

Profitable tax-paying entities are a fundamental driver of the U.S. renewable energy tax-benefit model. Without adequate tax liability, traditional tax credits and deductions cannot be used efficiently and, therefore, do not entice renewable energy investment. And while recent federal legislation has attempted to address this need in the short term (discussed in Section 5), the uncertainty surrounding the execution of those laws means that tax equity continues to be the main source of RE project investment through the first half of 2009.

Interviewees observed that the market for traditional tax equity investment has declined substantially both in the number of tax equity players and the actual funds available to invest. The number of investors has fallen as a result of insolvencies, bankruptcies, and consolidation. Frequently mentioned examples of such firms were AIG, Lehman Brothers, and Merrill Lynch. Additionally, in a merger and acquisition arrangement, an acquiring corporation must absorb any losses incurred by the acquired company (e.g., Wells Fargo absorbs Wachovia's losses). This further erodes the resulting entity's remaining profitability base and likely tax liabilities, which affects their probable amount of tax equity investment in the future. According to discussions

\footnotetext{
${ }^{3}$ The alternative minimum tax is a secondary tax system with separate rules and rates; taxpayers must pay the greater of either the AMT, or their regular taxes (including all tax credits and deductions). The AMT is designed to prevent individuals and corporations from reducing their income tax liability below a certain level (hence, it is a minimum tax level that must be paid).
} 
during a webinar hosted by Chadbourne \& Parke, only about four traditional tax equity investors remain active in early 2009 (Chadbourne \& Parke 2009b).

As shown in Figure 1, Hudson Clean Energy Partners foresees a sharp contraction in the pool of active tax equity investors in 2009 (down to four to six), with possible recovery in future years. ${ }^{4}$ Because today's market is in flux, other tax equity investors may exist and circumstances may change for current investors.

\section{Tax Equity Investor Base}

The Tax Equity Investor Base Cannot be Expected to Support this Transaction Volume

- The tax equity investor base has dwindled from approximately 20 investors in 2007, to approximately 5 investors in 2009

- Some tax equity investors may return to the market if tax credit carryback limitations are eased

- However, it is unrealistic to assume that the remaining investor base can support the tax equity transaction volumes necessary to achieve the twin targets of doubling renewable energy generation by 2011 and achieving $10 \%$ market penetration by 2012 target

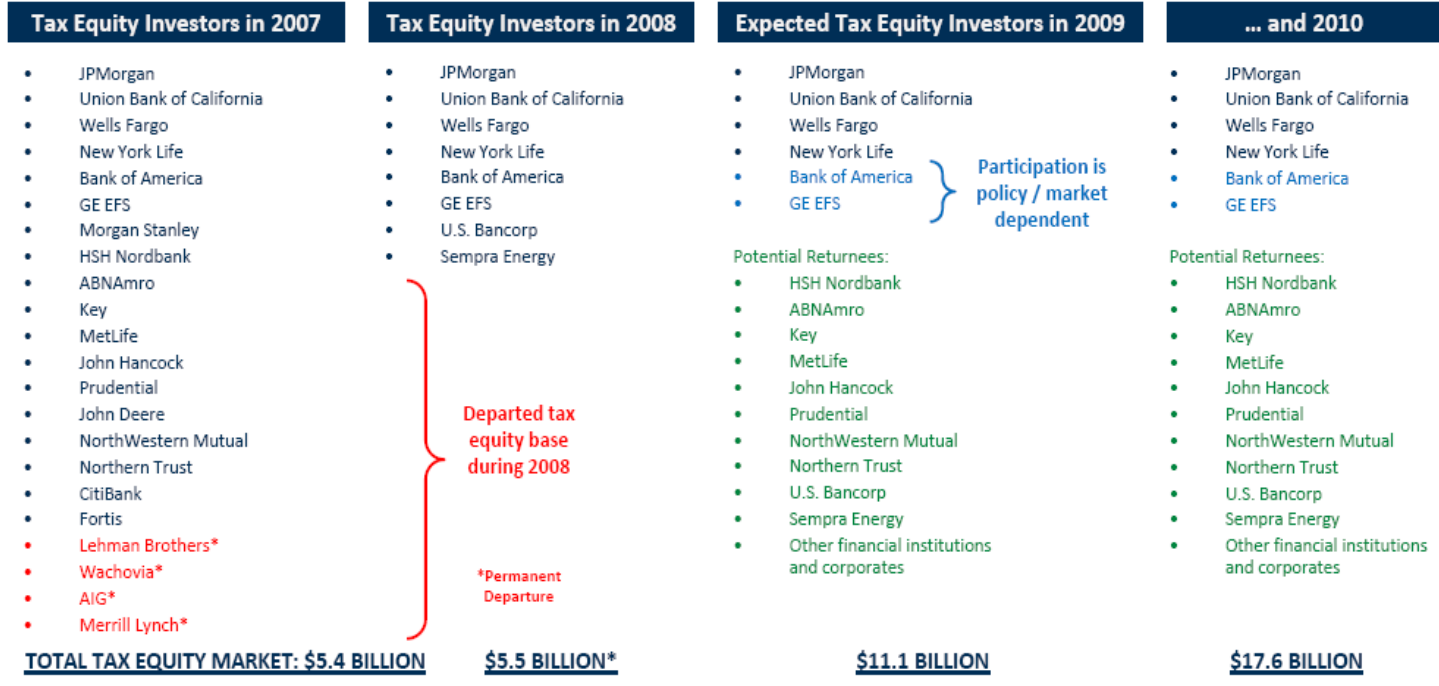

Sources: New Energy Finance, GreenTechMedia, JPMorgan and Hudson estimates

HUDSON

CLEANENERGY

Source: Hudson 2009

Figure 1. Recent and expected tax equity investors

Under current circumstances, a syndicate of several investors may be required to support a project because the funding pool of available tax equity investment is limited in the short term. This increases transactions costs and slows project development. As a result, renewable energy project development has slowed overall and only the best projects with solid management teams

\footnotetext{
${ }^{4}$ For example, in December 2008, Darren Van't Hof, a vice president with U.S. Bancorp Community Development Corporation said "As far as the bank is concerned, we have a strong tax credit appetite. We have good cash and liquidity positions. We are open for business. We are not actually doing any wind right now. We are not doing geothermal or biomass. We looked at wind a year ago and it wasn't that appealing. We might look at it again." (Chadbourne \& Parke 2009b).
} 
are likely to move forward in the short term. This was repeatedly described as a "flight to quality" by investors.

Responses and highlights from expert interviews:

Tax liabilities of remaining traditional tax equity investors

- "This was not a large universe to begin with."

- Tax equity investment has "completely and totally dried up."

- This is "unlike anything we have ever seen."

- Tax equity investors are "running for shelter."

- "Only four tax equity investors remain active."

- "We are open for business, but we are looking for high-quality off-takers, warranties, and low operating risk."

\subsection{Upward Pressure on Tax Equity Investment Returns}

Tax equity investors receive tax benefits equal to their initial capital contribution plus a return on the investment known as the internal rate of return (IRR). As a result of the tax equity market contraction, projects must compete for the limited sources of investment, and thus the rates of return necessary to attract investment have increased.

In early to mid-2008, deals were completed with tax equity IRR being in the mid-7\% range (Chadbourne \& Parke 2009b). However, renewable energy project IRRs must also compete with other tax equity investment opportunities such as affordable housing that set an effective floor on rates of return. Affordable housing is typically seen as a less-risky tax equity investment opportunity because it poses no operational risk (i.e., tax credits are received at the time of investment, not based on production, as with the PTC). Today, affordable housing yields are in the mid-8\% range and trending upward (Chadbourne \& Parke 2009b). While no specific consensus emerged, interviewees indicated that equity returns necessary to attract renewable energy project investment may increase anywhere from mid- $8 \%$ to as high as $15 \%$.

\section{Responses and highlights from expert interviews:}

\section{Tax equity IRR}

- "Tax equity takers at any price."

- "Projects are chasing capital."

- "Before, a developer was able to get a commitment on tax equity yields for several months that could be locked in...Now, the longer it takes to finance a project, the more uncertain [are the] IRRs."

- "An IRR of 7\%-8\% will not be high enough for renewable energy to compete for equity; renewables compete with affordable housing, and their yields are in the $8 . X \%$ range, and are trending upward. The advantage of affordable housing is there is no performance risk." 


\section{Debt Financing for Renewable Projects}

Although not as common as the tax equity model of finance, some renewable energy projects have used project- or corporate-level debt to fund development. Most renewable energy debt lending has happened at the corporate level as a backstop to equity investment in one or more projects. At the project level, debt is more commonly used-particularly for wind projectsduring project construction, although it is used on occasion to secure capital for the project itself.

\subsection{Illiquid Debt Market Results From the Financial Crisis}

As a result of the financial crisis and a tightening of credit worldwide, debt markets have seen a dramatic reduction in liquidity. For project developers, the availability of debt financing decreased significantly in 2008 and the first half of 2009 as the market shifted from borroweroriented to creditor-friendly. Debt lending for U.S. renewable energy projects has been dominated by a small number of European banks, and key lenders such as Fortis and Dexia are facing financial difficulties. As such, the pool of active debt lenders is limited in the short term.

The loan guarantees ${ }^{5}$ offered in ARRA and administered by the Department of Energy may increase the availability of project-level debt to finance renewable energy projects.

However, it will take time for the Department of Energy to set up the loan guarantee systemand as of June 2009, the market does not understand the process of application and approval. To accelerate this process, Secretary of Energy Steven Chu has announced changes to the way that grants and loans are offered from the department (DOE 2009). These changes are anticipated to accelerate funding distribution and quickly establish support mechanisms for developers who want to secure debt financing.

\section{Responses and highlights from expert interviews:}

Debt-lending availability

- "Precipitous reduction in liquidity."

- "Debt market was effectively closed for Q4 of 2008."

- Debt markets are still closed in early 2009 - "we need to understand how the DOE loan guarantees will work."

- Banks are "retrenching"

- "Where on Earth is lending available?"

\subsection{Interest Rates on Renewable Energy Debt Unclear; Expected Upward Trend}

Interest rates for debt on renewable energy projects are unclear because little, if any, debt is being financed in the commercial market. Without transactions, there is little data to quantify interest rates. Before the financial crisis, renewable energy project debt was reported to be at a premium of approximately 200-300 basis points (Chadbourne \& Parke 2009b) above a public financial indicator, such as LIBOR. ${ }^{6}$ This cost of debt financing is likely to increase as project

\footnotetext{
${ }^{5}$ For more details, see Section 5 or the Appendix.

${ }^{6}$ London Interbank Offered Rate (LIBOR) is the rate at which banks will borrow from other banks. LIBOR is a standard benchmark for short-term interest rates (Investopedia 2009).
} 
borrowers may pay a higher premium to secure the limited capital, despite reductions in general interest rates by central banks (Doyle 2009).

There was a general consensus among interviewees that the risk from debt has been repriced to higher levels because previous debt lenders may be conserving capital. Interviewees indicated that it was difficult to tell where the exact interest rates for RE projects stand without execution of landmark deals. There was no agreement where future debt interest rates for renewable energy projects would settle.

In addition, analysts speculate that the maximum term of debt for a renewable project is likely to top out at 15 years or less, but the term will depend on technology and other project-specific factors such as the length of off-take contract (ACORE 2008).

\section{Responses and highlights from expert interviews:}

\section{Interest rates}

- "LIBOR is broken, the new LIBOR is 150 basis points above LIBOR."

- Before the financial crisis:

"Money was practically free..."

"It was the best time to be a borrower in the energy industry since the independent power producer (IPP) boom of the early '90s."

- "Financing people have short memories...debt will flow again, eventually."

\section{Federal Policy Solutions}

In 2008 and 2009, the U.S. Congress enacted new legislation in an attempt to settle the U.S. financial markets and stimulate economic recovery. The Emergency Economic Stabilization Act of 2008 (EESA) and the American Recovery and Reinvestment Act of 2009 (ARRA) both contained sweeping measures aimed at stimulating many areas of the economy. The solutions that focus on the financing and development of renewable energy projects are addressed below.

\subsection{Effectiveness of EESA Unclear}

EESA was designed to inject capital into banks, provide liquidity to the credit markets, and restore confidence in the U.S. financial system. Several renewable energy-specific provisions were included in the legislation: notably an eight-year solar ITC extension, a one-year wind PTC extension, ${ }^{7}$ and allowance of the ITC to count against a project owner's alternative minimum tax. A detailed description of the renewable energy provisions can be found in the Appendix.

Interviewees agreed that it is still too early to tell whether the measures in EESA will stimulate the tax equity and debt markets, and encourage renewable energy investment again. The longterm ITC extension is considered beneficial because it eventually will allow for long-term capital planning once the debt and tax equity markets stabilize. Interviewees expressed concerns that, in

\footnotetext{
${ }^{7}$ For non-wind technologies, the PTC was extended for two years.
} 
the immediate future, effects of a potentially deep and far-reaching recession may temporarily outweigh the benefits of the targeted renewable energy provisions included in EESA.

\subsection{Effectiveness of ARRA's Renewable Energy Provisions Yet to Be Determined}

In February 2009, the U.S. federal government enacted ARRA, a nearly $\$ 800$ billion economic stimulus bill that was composed of spending and tax cuts. Under the act, the energy efficiency and renewable energy sectors will receive more than $\$ 71$ billion in newly appropriated funding, plus another $\$ 20$ billion in additional tax credit incentives (Weiss 2009). Selected renewable taxbased provisions of the bill include:

- Extending the PTC expiration by an additional three years over the EESA extensions (to 2012 for wind and 2013 for other technologies).

- Allowing the PTC to be converted into a 30\% ITC.

- Allowing federal cash grants to be taken in lieu of the ITC, administered by the Department of the Treasury.

- Removing subsidized energy financing ${ }^{8}$ restrictions of the ITC.

- Extending the 50\% first-year MACRS depreciation ("bonus accelerated depreciation”) to year-end 2009.

- Funding an additional \$6 billion in loan guarantees for renewable energy technologies, including commercially available technology projects (not previously eligible), emerging technology projects, transmission (not previously eligible), and manufacturing. This provision, administered by the Department of Energy, is expected to leverage $\$ 60$ billion to $\$ 100$ billion in projects.

- Providing an additional \$1.6 billion allocation for clean renewable energy bonds (CREBs) to municipalities, municipal utilities, and rural cooperatives $(\$ 2.4$ billion total, including EESA 2008).

ARRA attempts to addresses the shortage of tax equity investment by having the Department of the Treasury provide cash-based grants for property placed in service in 2009-2010, instead of tax credits (which do not function well if investors are not profitable). The cash-based grants would be a stop-gap measure until tax equity investment returns to the market - most likely with increased profitability and a healthier economy in a few years. Only tax-paying commercial entities would be able to apply for this cash-based grant, which excludes government agencies and certain other entities that do not pay taxes. And because the "passive-loss and at-risk rules" persist, it is still challenging for high net-worth individuals with large tax appetites to take the PTC and ITC directly on their personal income taxes.

While the cash grants should help with the ITC and PTC (by way of the option to elect the ITC), traditional tax equity liability is still needed to benefit from MACRS accelerated depreciation. The option of choosing the ITC instead of the PTC would shorten the length of time needed to fully secure the benefits of either the tax credit or the grant from 10-11 years (PTC benefit) to six years (MACRS). Conversely, other factors may favor the election of the PTC over the ITC, but would need to be considered on an individual project basis (Bolinger et al. 2009).

\footnotetext{
${ }^{8}$ Subsidized energy financing (SEF) refers to federal, state, or local governmental program assistance (e.g., zerointerest loans). Previously, the portion of the project financed using SEF was not eligible to use the ITC.
} 
ARRA's three-year PTC extension provides longer-term certainty of the tax incentive than the previous one- to two-year extensions allowed - a provision that should assist renewable project capital planning. However, this PTC extension is shorter than the eight-year ITC extension established in EESA. In addition, the loan guarantees and new allocations for clean renewable energy bonds ${ }^{9}$ as well as qualified energy conservation bonds should help funnel investment into the industry, separate from the PTC and ITC mechanisms.

\subsection{Measures to Monitor the Impact of Federal Legislation on RE Project Development}

It is too early to assess definitively the degree to which the enactment of EESA and ARRA may serve the renewable energy industry from today's market conditions. Given the amount of money likely to flood the renewable energy markets, the impact is likely to be pronounced - the question is when it will occur.

As the programs are implemented, a few indicators could help gauge the effectiveness of the renewable energy provisions. One important factor is the timing of implementation of federal legislation, or how long it takes to provide clarity to investors and the market. In most parts of the United States, there is a clearly defined construction season-and if it is missed in 2009, then projects cannot be completed until 2010. It will be important to see whether construction has enough time for completion in 2009 after guidance and application documents are issued. If some projects miss the construction window, effectiveness may depend on whether the market is able to execute additional construction in 2010.

The cash grant and loan guarantee programs are expected to provide the most-needed benefit to the market as other sources of equity and debt investment are constrained. Thus, expediency of program implementation and administration are imperative to providing meaningful and timely assistance. To be effective, program details and guidance must be understandably defined to satisfy all contractual or interested parties. These federal incentives should also provide longterm certainty to the market, specifically to facilitate capital planning and investment in future development.

In tracking the legislation, it will also be useful to monitor early signs of economic recovery or a stabilization of the financial markets. Such signals could precede a rebound and resurgence of renewable energy project development and a stabilization of the industry. Lastly, the emergence of new or returning investors through these programs is critical to expanding the limited investment pool and is addressed in Section 6.

\footnotetext{
${ }^{9}$ Clean renewable energy bonds, or CREBS, are used as an RE project financing source for municipalities, rural electric cooperatives, and municipal utilities.
} 


\section{New Investor Opportunities}

Traditionally, renewable energy projects have relied heavily on tax equity capital investment from the financial sector, which limited investment. As a result of the financial crisis and subsequent federal legislation, developers may need to expand their sources of capital investment.

\subsection{New Tax Equity Investors Anticipated}

The contraction of traditional tax equity investors and expected increase in IRR could open the door to new investors (outside of financial firms) for renewable energy projects. This is especially true with broader eligibility of the ITC under EESA. New or reemerging tax equity investors will be necessary for continued renewable energy project development; this may be particularly true after the expiration of the ARRA cash grant. The sample of experts interviewed expect that there will be an increased interest in projects being financed by untraditional, yet profitable companies that can take direct advantage of the PTC and ITC and do not require a third party. Possible new entrants as renewable energy tax equity investors could eventually come from a wide range of sectors including oil and gas, high-tech, and industrial companies.

Interviewees also mentioned that more tax equity could enter into the market if unconventional investors such as high net-worth individuals could take the tax credits (see Section 3.2)

(Chadbourne \& Parke 2009a). Federal legislation has not addressed the barriers that currently impede these investors.

\subsection{Utilities Increasingly Interested in Project Ownership and Tax Equity Investments}

Utilities were also widely mentioned by interviewees as possible tax equity investors who would have sufficient profitability levels to directly use tax credit investments (now and particularly in the long term). Increased utility involvement could simplify financing arrangements, replacing complex partnerships. Utilities can take the PTC for wind and other renewables (Cory et al. 2008, Mann 2008) so they may decide to own the renewable projects themselves. Also, utilities can now take the ITC directly, so they might structure programs to own distributed solar systems on their own land - or on their customer sites - particularly in load-constrained areas. Five utilities have already announced such plans including Duke Energy in North Carolina; Public Service Electric and Gas Co. in New Jersey; and three California utilities: Pacific Gas and Electric, San Diego Gas and Electric, and Southern California Edison (Baker 2009). 


\section{Responses and highlights from expert interviews: \\ Possibilities of new investors}

- “Utilities can't afford not to participate."

- "Technology and telecommunication companies are possible new investors...Companies such as Samsung, LG Electronics, Toshiba, and Siemens may step in through acquisitions"

- "Oil industry and railroad companies could become interested."

- "The industry cannot quickly replace the likes of JP Morgan, Wells Fargo, and CitiBank. Their experience investing in renewables will take time to redevelop."

- "Large owners of real estate could deploy many relatively small systems across their properties; they will likely enjoy economies of scale for pricing."

- "Hotels, insurance companies, and banks could enter the RE investment space. If returns go up enough, we could also see non-electric utilities, Microsoft, Google, Nike, Northern Trust, etc."

\section{Factors Influencing Future RE Project Development and Financing}

Renewable energy generation in the United States will be influenced by a number of factors in the near term. Among other considerations, the simultaneous impact of the financial crisis, U.S. federal legislation, new or re-emerging investors, as well as anticipated economic recovery will determine future renewable energy generation growth. Figure 2 depicts several projected growth scenarios, an estimate of the impact of the financial crisis, and a sequence of key market events for non-hydro renewable energy generation.

The low-growth scenario is the Energy Information Administration's (EIA's) projection of renewable energy generation without the passage of ARRA (EIA 2009a). The next highest growth scenario is EIA's revised projection to account for renewable energy provisions contained within ARRA (EIA 2009b). By 2012, the revised scenario projects nearly $150 \mathrm{TWh}$ of renewable energy generation in excess of the original projection. The high growth scenario is a post-ARRA, NREL estimate of renewable energy generation, indicating the largest increase among the three scenarios (Sullivan et al. 2009). Note that all scenarios indicate a drop in generation growth in 2013. This slowdown reflects the scheduled expiration of the PTC for wind at year-end 2012 .

A sequence of market events influencing renewable energy development is also depicted chronologically in Figure 2. Along the top of the figure is a timeline of market events. Each section of the timeline is depicted by an arrow that is coincident to a particular time period in which that event is expected to have its greatest impact on project development. Realistically, however, the true impact of each market event is extended - thus commencing before and continuing after the period in which it is sequentially aligned.

Lastly, an estimate of the duration of the financial crisis's impact on renewable energy project development is shown beginning at the height of the crisis in October 2008. In the wake of the 
financial crisis, renewable energy project development has continued. For instance, more than 2,800 MW of wind capacity was installed in the first quarter of 2009 (AWEA 2009b). However, much of the financing for these projects was secured prior to the height of the financial crisis, and commitments were honored by project investors. Accordingly, it is possible that the most acute impact of the financial crisis on renewable energy project development could be experienced in the second half of 2009. This is the period after pre-financial crisis commitments are completed, but before the impacts of the ARRA provisions or broader economic recovery take place. In Figure 2 this is shown as the range from the height of the financial crisis to yearend 2009.

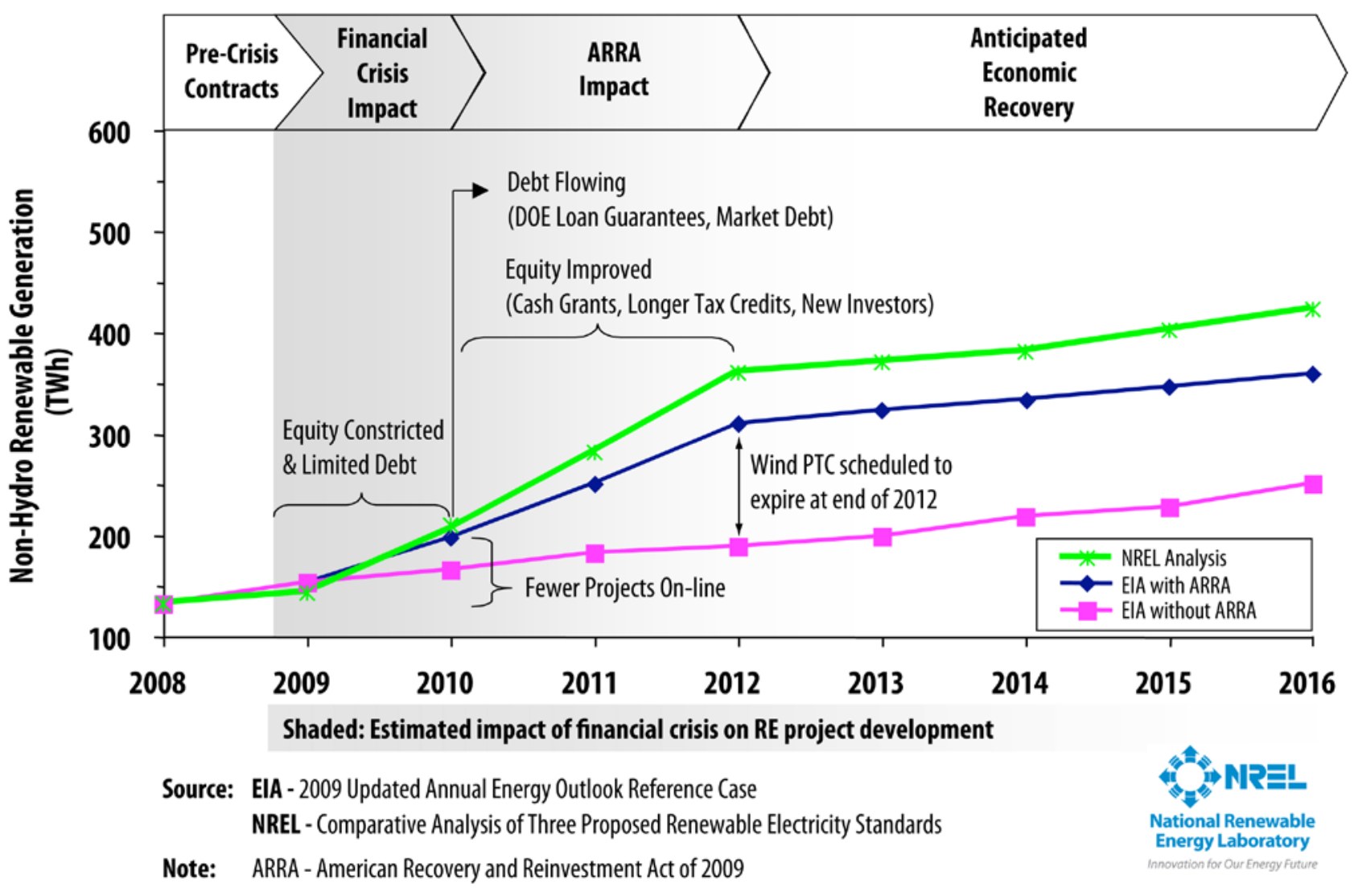

Figure 2. Impacts of the financial crisis and federal legislation on renewable energy project development 


\section{Conclusions}

Renewable energy project financing is being reshaped by several extraordinary market conditions. The two primary sources of project capital investment - tax equity investment and debt—are currently limited and are, therefore, a constraint on new project development.

The market for tax equity investment is sizably smaller than recent boom years. As of the first half of 2009, the amount of tax equity investment will be insufficient for near-term renewable energy project development. Utilities and other new investors may increasingly invest in renewable energy projects as equity returns are expected to increase. New investment is expected to be supported by the broader eligibility for tax equity investment under the Emergency Economic Stabilization Act of 2008, and the substitution of Department of Treasury cash grants for tax credits under the American Recovery and Reinvestment Act of 2009.

Meanwhile, little debt is currently available as a result of the financial crisis and the tightening of credit worldwide. As renewable energy project lenders are conserving capital, borrowing costs are expected to increase. However, as of this writing, interest rates for debt on renewable energy projects are unclear because little, if any, debt is being financed in the commercial market. The loan guarantees offered in ARRA and administered by the Department of Energy, may increase the availability of debt to finance renewable energy projects.

Critically, these new programs are hoped to signal a long-term commitment by the U.S. federal government in support of renewable energy. Long-term policy and program certainty is critical to capital planning and investment in project development. This commitment will help achieve consistent and sustained growth of renewable energy and assist in curbing the boom-and-bust cycle of project development that has plagued the industry.

The crippling financial and economic circumstances will also likely lead to a renewable energy industry shakeout. Industry consolidation is widely expected with the strongest capitalized firms or new market entrants acquiring distressed or thinly capitalized competitors. If the economy recovers in a timely fashion, best practices should prevail and the strongest firms will rise to the top. It is hoped that the industry as a whole will emerge stronger with a better understanding of the risks that it faces.

Overall, it appears that the financial crisis will impact U.S. renewable energy project development most acutely in the near term; however, major changes introduced by federal legislation are expected to stimulate growth in the months and years ahead. The nation is anxious to see how recent federal policies will help the U.S. economy recover. As the financing provisions from EESA and ARRA are fully implemented, experts are optimistic that the rate of renewable energy project development will accelerate. 


\section{References}

ACORE (2008). "Renewable Energy Finance - Hedging and Risk Management During Financial Markets in Turmoil," American Council On Renewable Energy (ACORE) webinar, moderated by Roger Stark, K\&L Gates; and John Lorentzen, Winston \& Strawn, November 19, 2008.

ARRA (2009). American Recovery and Reinvestment Act of 2009 (ARRA), H.R. 1105, $111^{\text {th }}$ Congress, first session (2009), at http://appropriations.house.gov/pdf/2009 Con Bill Introductory.pdf

AWEA (2009a). "WIND ENERGY GROWS BY RECORD 8,300 MW IN 2008," American Wind Energy Association (AWEA) news release, January 27, 2009, at http://www.awea.org/newsroom/releases/wind_energy_growth2008_27Jan09.html

AWEA (2009b). "U.S. Wind Energy Industry Installs Over 2,800 MW In First Quarter," American Wind Energy Association news release, April 28, 2009, at http://www.awea.org/newsroom/releases/AWEA_first_quarter_market_report 042809. $\underline{\mathrm{html}}$

Baker, D. R. (2009). "PG\&E bankrolling solar plants" San Francisco Chronicle, February 25, 2009, accessed at http://www.sfgate.com/cgibin/article.cgi?f=/c/a/2009/02/24/MNB1164F0P.DTL

Bolinger, M.; Wiser, R.; Cory, K.; James, T. (2009). "PTC, ITC, or Cash Grant? An Analysis of the Choice Facing Renewable Power Projects in the United States," Lawrence Berkeley National Laboratory and National Renewable Energy Laboratory technical report LBNL1642E and NREL/TP-6A2-45359, March 2009, at http://www.nrel.gov/docs/fy09osti/45359.pdf

Chadbourne \& Parke (2009a). “A Look Forward Into 2009," Project Finance NewsWire, a discussion in mid-December with four Washington lobbyists, moderated by Keith Martin, Chadbourne \& Parke, p. 3, released in January 2009, at http://www.chadbourne.com/files/Publication/810dde60-3c78-4a9a-9c5da5fae 8014b4f/Presentation/PublicationAttachment/51fc06c5-1407-48ac-9dffa605de0f58e1/pfn0109.pdf

Chadbourne \& Parke (2009b). "Trends in Tax Equity for Renewable Energy," Project Finance NewsWire, Infocast webinar with two equity arrangers and four potential renewable energy investors, moderated by Keith Martin, Chadbourne and Parke, pp. 27-34 on December 16, released in January 2009, at http://www.chadbourne.com/files/Publication/810dde60-3c78-4a9a-9c5da ffae 8014b4f/Presentation/PublicationAttachment/51fc06c5-1407-48ac-9dffa605de0f58e1/pfn0109.pdf 
Cory, K.; Coggeshall, C.; Coughlin, J.; Kreycik, C. (2009). "Solar Photovoltaic Financing: Deployment by Federal Government Agencies," National Renewable Energy Laboratory - forthcoming technical report that will be available in summer 2009, at http://www.nrel.gov/publications/

Cory, K.; Coughlin, J.; Jenkin, T.; Pater, J.; Swezey, B. (2008). "Innovations in Wind and Solar PV Financing," National Renewable Energy Laboratory Technical Report NREL/TP670-42919, February 2008, at http://www.nrel.gov/docs/fy08osti/42919.pdf

DOE (2009). "DOE Secretary Chu Announces Changes to Expedite Economic Recovery Funding: Restructuring will lead to new investments in energy projects within months," U.S. Department of Energy (DOE) news release, February 19, 2009, accessed at http://www.energy.gov/news2009/6934.htm

DOE (2008). “Annual Report on U.S. Wind Power Installation, Cost, and Performance Trends: 2007," U.S. Department of Energy's Office of Energy Efficiency and Renewable Energy - Wind Energy Technology Program, May 2008, at http://www1.eere.energy.gov/windandhydro/pdfs/43025.pdf

Doyle, J. (2009). “The Asset Finance Drought: Is There An Opening For Specialist Debt Funds?” New Energy Finance, May 13, 2009

EIA (2009a). “Annual Energy Outlook 2009 with Projections to 2030, Updated Annual Energy Outlook 2009 Reference Case without ARRA,” U.S. Department of Energy, Energy Information Administration (EIA) Web site, accessed June 2009 at http://www.eia.doe.gov/oiaf/servicerpt/stimulus/excel/aeonostimtab_16.xls

EIA (2009b). “Annual Energy Outlook 2009 with Projections to 2030, Updated Annual Energy Outlook 2009 Reference Case with ARRA," U.S. Department of Energy, Energy Information Administration website, accessed June 2009 at. http://www.eia.doe.gov/oiaf/servicerpt/stimulus/excel/aeostimtab_16.xls

EESA (2008). Emergency Economic Stabilization Act of 2008 (EESA), H.R. 1424, $110^{\text {th }}$ Congress, second session (2008), at http://www.govtrack.us/congress/billtext.xpd?bill=h110-1424

Harper, J.; Karcher, M.; Bolinger, M. (2007). "Wind Project Financing Structures: A Review \& Comparative Analysis," Lawrence Berkeley National Laboratory technical report LBNL63434, September 2007, at http://eetd.lbl.gov/ea/ems/reports/63434.pdf

Hudson (2009). "Additional Observations About the Impact of Stimulus Action on Energy and Environmental Policy” Hudson Clean Energy Partners, L.P, accessed June 2009 at http://www.seia.org/galleries/pdf/Need_for_Refundability.pdf 
Investopedia (2009). "London Interbank Offered Rate - LIBOR. Investopedia explains London Interbank Offered Rate - LIBOR,” Investopedia: A Forbes Digital Company, accessed February 2009, at http://www.investopedia.com/terms///libor.asp

Mann, L. (2008). "IRS Reinterpretation Will Benefit Utilities RE Investments," North American Windpower, September 2008, pp. 72-73.

Prometheus (2007). “U.S. Solar Industry: Year in Review 2007," Prometheus Institute and the Solar Energy Industries Association, accessed December 2008 at http://www.seia.org/galleries/pdf/Year_in_Review_2007_sm.pdf

SEIA (2009). "US Solar Industry Year in Review 2008," Solar Energy Industries Association (SEIA), accessed June 2008 at http://seia.org/galleries/pdf/2008 Year_in_Review-small.pdf

Sullivan, P.; Logan, J.; Bird, L.; Short, W. (2009). "Comparative Analysis of Three Proposed Renewable Electricity Standards," National Renewable Energy Laboratory technical report NREL/TP-6A2-45877, May 2009, at http://www.nrel.gov/docs/fy09osti/45877.pdf

Weiss, D.J.; Kougentakis, A. (2009). "Recovery Plan Captures the Energy Opportunity," Center for American Progress, February 13, 2009, at http://www.americanprogress.org/issues/2009/02/recovery_plan_captures.html 


\section{Appendix. Select Federal Legislation in 2008 and 2009}

\section{Emergency Economic Stabilization Act of 2008}

In an effort to restore confidence and functionality of the financial markets, the U.S. federal government passed the Emergency Economic Stabilization Act of 2008 (EESA). While its main goal was to try to support investors and lenders, EESA included several renewable energy provisions that applied to a number of renewable energy technologies and varied in both scope and length. The key provisions are identified below (EESA 2008).

- Extension of the production tax credit by one year to the placed-in-service date of December 31, 2009, for wind; and December 31, 2010, for biomass, marine, and certain other renewable sources.

- Extension of the investment tax credit at a rate of $30 \%$ by eight years for solar and qualified fuel cells through 2016, and $10 \%$ for microturbines. The $\$ 2,000$ ITC cap for residential solar was lifted (so they can now take the full $30 \%$ ). EESA also added two new technologies to the eligibility list: small wind $(<100 \mathrm{~kW})$ and geothermal heat pumps. EESA established a $\$ 4,000$ cap for each small wind project. At the end of the eight-year period, the $30 \%$ tax rate will revert back to $10 \%$ and the microturbines tax credit will expire.

- Allowance of the investment tax credit to count against the alternative minimum tax, which opens up the tax credit to many more investors.

- Allowance for utilities to take the investment tax credit.

- Authorization of $\$ 800$ million to fund new clean renewable energy bonds for municipalities, rural electric cooperatives, and municipal utilities, across various technologies.

- Authorization of $\$ 800$ million to fund qualified energy conservation bonds across various technologies.

\section{American Recovery and Reinvestment Act of 2009}

On February 17, 2009, President Obama signed into law the American Recovery and Reinvestment Act of 2009, which included several renewables-specific provisions, shown in Table A1 (ARRA 2009). 
Table A1. Select Tax Provisions Addressing EERE Sectors

Extends the PTC

In-Service Deadline

Provides Option to

Elect the ITC in

Lieu of the PTC ${ }^{10}$

Provides Option to

Elect a Cash Grant

in Lieu of the ITC

Removes ITC

Subsidized Energy

Financing Penalty

Extends $50 \%$

Bonus Depreciation

Extends Loss

Carryback Period

Removes ITC

Dollar Caps

Expands Loan

Guarantee Program

Clean Renewable

Energy Bonds

New ITC for

Manufacturers

Energy

Conservation

Bonds

Residential

Efficiency

Upgrades

Credits

PHEV Consumer

Tax Credit

Alternative Fuel

Tax Credits for

Infrastructure

Extends the PTC through 2012 for wind, and through 2013 for closed- and open-loop

biomass, geothermal, landfill gas, municipal solid waste, qualified hydroelectric, and marine and hydrokinetic facilities. In 2008, the inflated PTC stood at \$21/MWh for wind,

geothermal, and closed-loop biomass; and \$10/MWh for other eligible technologies.

Allows PTC-qualified facilities installed in 2009-13 (2009-12 in the case of wind) to elect a $30 \%$ ITC in lieu of the PTC. If the ITC is chosen, the election is irrevocable and requires the depreciable basis of the property to be reduced by one-half the amount of the ITC.

Creates a new program (administered by the Treasury) to provide grants covering up to $30 \%$ of the cost basis of qualified renewable energy projects that are placed in service in 2009-10, or that commence construction during 2009-10 and are placed in service prior to 2013 for wind, 2017 for solar, and 2014 for other qualified technologies. Applications must be submitted by October 1, 2011, and the Treasury is required to make payments within 60 days after an application is received or the project is placed in service, whichever is later. The grant is excluded from gross income, and the depreciable basis of the property must be reduced by one-half of the grant amount.

Allows projects that elect the ITC to also use "subsidized energy financing" (e.g., tax-exempt bonds or low-interest loan programs) without suffering a corresponding tax credit basis reduction. This provision also applies to the new grant option described above.

Extends $50 \%$ bonus depreciation (i.e., the ability to write off $50 \%$ of the depreciable basis in the first year, with the remaining basis depreciated as normal according to the applicable schedules) to qualified renewable energy projects acquired and placed in service in 2009.

Extends the carryback of net operating losses from two to five years for all small businesses (i.e., those with average annual gross receipts of $\$ 15$ million or less over the most recent three-year period). This carryback extension can only be applied to a single tax year, which must either begin or end in 2008.

Eliminates the maximum dollar caps on residential small wind, solar hot water, and geothermal heat pump ITCs (so now at the full 30\%). Also eliminates the dollar cap on the commercial small wind $30 \%$ ITC. Credits may be claimed against the AMT.

Expands existing loan guarantee program to cover commercial (rather than just "innovative noncommercial") projects. Appropriates $\$ 6$ billion to reduce or eliminate the cost of providing the guarantee; this amount could support $\$ 60-\$ 120$ billion in loans, depending on the risk profiles of the underlying projects.

Adds $\$ 1.6$ billion in new CREBs for eligible technologies owned by governmental or tribal entities, as well as municipal utilities and cooperatives. With $\$ 800$ million of new CREB funding previously added in October 2008, combined new CREB funding totals $\$ 2.4$ billion.

Establishes a $30 \%$ ITC for the establishment, expansion, or retooling of manufacturing facilities producing clean energy and related technologies. Projects must be certified by the Treasury in consultation with DOE.

Adds $\$ 2.4$ billion to state, local, and tribal programs to finance clean energy projects. This is a four-fold increase from the previous maximum level of available funding.

Increases the credit to $30 \%$ (a three-fold increase) for 2009 and 2010 with a $\$ 1,500$ cap, and removes limits on certain properties and other subsidized energy financing.

Modifies the tax credit for consumers of plug-in hybrid electric vehicles (PHEVs) to a maximum of $\$ 7,500$ and eliminates some previous restrictions to spur the development of PHEV markets.

Increases refueling property tax credits for 2009 and 2010:

- Businesses - Increases from 30\% (capped at $\$ 30,000$ ) to 50\% (capped at $\$ 50,000$ ).

- Individuals - Increases from 30\% (capped at $\$ 1,000$ ) to 50\% (capped at $\$ 2,000$ ).

- Hydrogen refueling pumps remain at $30 \%$ with a cap increase to $\$ 200,000$.

Created by Ted James and Jeffrey Logan, NREL, in March 2009; includes input from Mark Bolinger and Ryan Wiser, LBNL.

\footnotetext{
${ }^{10}$ For analysis on this new option, see Bolinger et al. 2009.
} 


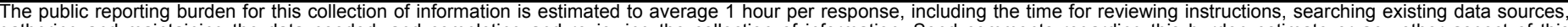

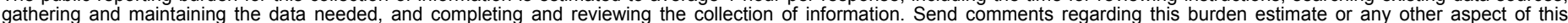

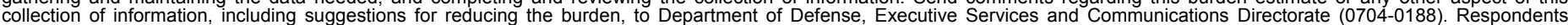

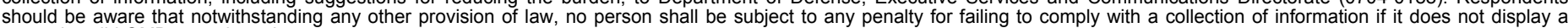

should be aware that notwithstanding

PLEASE DO NOT RETURN YOUR FORM TO THE ABOVE ORGANIZATION.

\begin{tabular}{l|l|l|l} 
1. REPORT DATE (DD-MM-YYYY) & 2. REPORT TYPE & 3. DATES COVERED (FrOm - TO)
\end{tabular} July 2009

Technical Report

4. TITLE AND SUBTITLE

Renewable Energy Project Financing: Impacts of the Financial

Crisis and Federal Legislation 5a. CONTRACT NUMBER

DE-AC36-99-G010337

5b. GRANT NUMBER

5c. PROGRAM ELEMENT NUMBER

5d. PROJECT NUMBER

NREL/TP-6A2-44930

5e. TASK NUMBER

SA07.9B30

5f. WORK UNIT NUMBER
7. PERFORMING ORGANIZATION NAME(S) AND ADDRESS(ES)

National Renewable Energy Laboratory

1617 Cole Blvd.

Golden, CO 80401-3393
8. PERFORMING ORGANIZATION REPORT NUMBER

NREL/TP-6A2-44930

9. SPONSORING/MONITORING AGENCY NAME(S) AND ADDRESS(ES)

10. SPONSOR/MONITOR'S ACRONYM(S) NREL

11. SPONSORING/MONITORING AGENCY REPORT NUMBER

12. DISTRIBUTION AVAILABILITY STATEMENT

National Technical Information Service

U.S. Department of Commerce

5285 Port Royal Road

Springfield, VA 22161

13. SUPPLEMENTARY NOTES

14. ABSTRACT (Maximum 200 Words)

Extraordinary financial market conditions have disrupted the flows of equity and debt investment into U.S. renewable energy (RE) projects since the fourth quarter of 2008. The pace and structure of renewable energy project finance has been reshaped by a combination of forces, including the financial crisis, global economic recession, and major changes in federal legislation affecting renewable energy finance. This report explores the impacts of these key market events on renewable energy project financing and development.

\section{SUBJECT TERMS}

NREL; renewable energy; RE; financial crisis; production tax credit; PTC; American Recovery and Reinvestment Act of 2009; ARRA; Emergency Economic Stabilization Act of 2008; EESA; renewable portfolio standard; RPS; renewable energy certificate; REC; renewable energy markets; Paul Schwabe; Karlynn Cory

\begin{tabular}{|c|c|c|c|c|}
\hline \multicolumn{3}{|c|}{ 16. SECURITY CLASSIFICATION OF: } & \multirow{2}{*}{$\begin{array}{l}\text { 17. LIMITATION } \\
\text { OF ABSTRACT } \\
\text { UL }\end{array}$} & \multirow{2}{*}{$\begin{array}{l}\text { 18. NUMBER } \\
\text { OF PAGES }\end{array}$} \\
\hline $\begin{array}{l}\text { a. REPORT } \\
\text { Unclassified }\end{array}$ & $\begin{array}{l}\text { b. ABSTRACT } \\
\text { Unclassified }\end{array}$ & $\begin{array}{l}\text { c. THIS PAGE } \\
\text { Unclassified }\end{array}$ & & \\
\hline
\end{tabular}

19a. NAME OF RESPONSIBLE PERSON

19b. TELEPHONE NUMBER (Include area code) 